\title{
Hypersecretion of Glucagon and Gastrin in Severely Burnt Patients
}

\author{
C. I. ORTON, \\ A. W. SEGAL, \\ S. R. BLOOM, J. CLARKE
}

British Medical fournal, 1975, 2, 170-172

\section{Summary}

Hyperglucagonaemia and hypergastrinaemia were observed in some severely burnt patients during their illness. Hyperglucagonaemia seemed to be related to the severity of illness rather than to the burn itself, and the close correlation of glucagon concentrations with glucose and urea and its inverse correlation with bicarbonate concentrations suggest that glucagon might contribute to the hypercatabolic state. One patient developed high levels of gastrin and massive bleeding from a stress ulcer of the duodenum. Possibly gastrin hypersecretion may have a role in the pathogenesis of Curling's ulcer.

\section{Introduction}

Thermal burns may be complicated by complex biochemical changes and by haemorrhage from acute ulceration of the gastrointestinal tract. We studied burnt patients to determine the changes in serum concentrations of two independent hormones, glucagon, and gastrin. Factors associated with their secretion and a possible causal relationship between the secretion of glucagon and biochemical changes and the secretion of gastrin and acute stress ulceration of the gastrointestinal tract were investigated.

\section{Patients and Methods}

Fifteen consecutive adult patients (seven men and eight women, mean age 47.9) admitted within 12 hours of a thermal burn were studied. All patients were treated by exposure in a temperature of $27^{\circ}-30^{\circ} \mathrm{C}$ $\left(80^{\circ}-85^{\circ} \mathrm{F}\right){ }^{1}$ and those with burns to over $15 \%$ of the body surface received intravenous fluids, including a high molecular weight plasma expander (dextran 110), and blood when necessary. All patients fasted for eight hours overnight and received only intravenous saline for six hours before the withdrawal of blood samples, which were obtained daily during the initial shock phase and then thrice weekly in most cases.

Plasma glucagon and gastrin concentrations were estimated by radioimmunoassay. ${ }^{2}$ The glucagon assay used a specific pancreatic glucagon antiserum (C-terminal reacting) with M.R.C. 69/104 glucagon standards made up in glucagon-free plasma, and the gastrin assay used an antiserum which reacted fully with G17 and about $50 \%$ with $\mathrm{G} 34,{ }^{3}$ thus approximately reflecting the acid-stimulating ability of plasma gastrins ${ }^{4}$ and M.R.C. 68/439 gastrin standards. Normal values for glucagon (15-90 ng/l) and gastrin (2-50 ng/l) were obtained from a group of 21 volunteers of similar age distribution,

\footnotetext{
Plastic Surgery and Burns Centre, Queen Mary's Hospital, Roehampton

C. I. ORTON, M.B., F.R.C.s., Senior House Officer (Present appointment: Registrar, Regional Plastic Surgery Centre, St. Andrew's Hospital, Billericay)

J. CLARKE, M.B., F.R.C.s., Registrar

Northwick Park Hospital and Clinical Research Centre, Harrow, Middlesex

A. W. SEGAL, M.D., M.R.C.P., Clinical Research Registrar

Hammersmith Hospital, London W12 0HS

S. R. BLOOM, M.B., M.R.C.P., Lecturer and Honorary Consultant
}

whose samples were assayed at the same time as those from the patients. Serum glucose, urea, bicarbonate, and electrolytes were measured on an Auto Analyzer, and full blood counts were performed on a Coulter counter model $S$.

At the time of blood sampling patients were clinically divided into four groups according to the systemic manifestations of disease. Patients in group 1 were regarded as fit apart from their burn injury, those in group 2 showed minor complications such as pyrexia or a respiratory tract infection, those in group 3 had major complicationsfor example, septicaemia or pulmonary embolism-but they were expected to recover from their disease, unlike those in group 4 whose likelihood of survival seemed small. Group 4 patients tended to have a combination of major disorders and were collapsed or hypotensive with a concomitant drop in level consciousness. The assessment was performed each day by one of the two clinicians (I.C., C.I.O.) and was thus independent of any laboratory measurements. All faeces were examined for the presence of blood (Okokit, Hughes and Hughes). Routine bacteriological studies were performed, as were blood cultures when indicated. Necropsies were performed on patients who died.

\section{Results}

Seven patients died from their burns (table 1). Plasma gastrin levels were not generally raised (fig. 1), levels greater than $120 \mathrm{ng} / 1$ occurring in only two patients. One of these (case 4) had consistently high levels (570-660 $\mathrm{ng} / \mathrm{l})$ and seemed to have had pernicious anaemia. The second (case 5) was the only patient to have frank gastrointestinal haemorrhage and positive results on occult blood estimations, and acute stress ulceration of the gastrointestinal tract was observed at necropsy. His peak gastrin concentrations coincided with the onset of bleeding from a Curling's ulcer in the second part of the duodenum.

Though gastrin concentrations seemed to be related to the severity of illness this only becomes statistically significant between patients in groups 1 and 4 (P<0.01; table II, fig. 2). There was no relation between gastrin concentration and body temperature, total white blood count, and blood glucose (table III). The gastrin concentration correlated with the blood urea $(\mathbf{P}<0.01)$ and inversely with the serum bicarbonate $(P<0.05)$.

Plasma glucagon concentrations were raised above normal at some time in most patients. There was also a significant correlation between the total surface area of the burn, expressed as percentage of body area, and serum glucagon levels $(r=0.66 ; P<0.01)$. These increases seemed, however, to be more closely related to the severity of illness than to the burn per se (figs. 2). Concentrations greater than $250 \mathrm{ng} / \mathrm{l}$

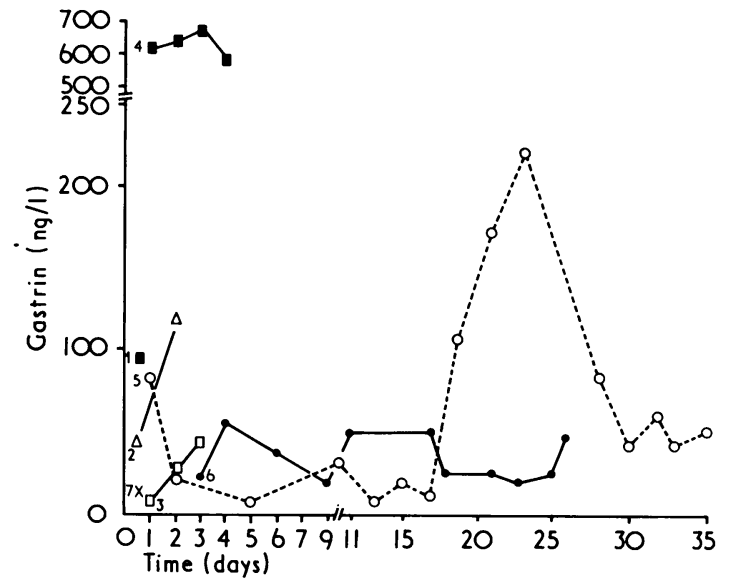

FIG. 1-Plasma gastrin concentrations in seven patients who died of burns. Case numbers are given. 
TABLE I-Details of Patients Studied

\begin{tabular}{|c|c|c|c|c|c|c|c|c|c|c|}
\hline \multirow[b]{2}{*}{$\begin{array}{l}\text { Case } \\
\text { No. }\end{array}$} & \multirow[b]{2}{*}{$\begin{array}{l}\text { Age } \\
\text { (Years) }\end{array}$} & \multirow[b]{2}{*}{ Sex } & \multicolumn{2}{|c|}{ Burn } & \multicolumn{3}{|c|}{ Glucagon } & \multicolumn{2}{|r|}{ Gastrin } & \multirow[b]{2}{*}{$\underset{(\mathbf{n g} / \mathbf{l})}{\text { Range }}$} \\
\hline & & & Total & $\begin{array}{c}\text { Full } \\
\text { Depth }\end{array}$ & $\begin{array}{l}\text { No. of } \\
\text { Samples }\end{array}$ & $\underset{\text { of Mean }}{\operatorname{Mean}( \pm \text { S.E. })}$ & $\begin{array}{l}\text { Range } \\
\text { (ng/l) }\end{array}$ & $\begin{array}{l}\text { No. of } \\
\text { Samples }\end{array}$ & $\begin{array}{l}\text { Mean ( } \pm \text { S.E.) } \\
\text { of Mean (ng/l) }\end{array}$ & \\
\hline \multicolumn{11}{|c|}{ Fatalities } \\
\hline $\begin{array}{l}1 \\
2 \\
3 \\
4 \\
5 \\
6 \\
7 \\
\end{array}$ & $\begin{array}{l}20 \\
76 \\
65 \\
80 \\
34 \\
76 \\
77 \\
\end{array}$ & $\begin{array}{l}\text { M. } \\
\text { F. } \\
\text { F. } \\
\text { F. } \\
\text { M. } \\
\text { F. } \\
\text { M. }\end{array}$ & $\begin{array}{l}85 \\
80 \\
65 \\
50 \\
40 \\
20 \\
20\end{array}$ & $\begin{array}{l}85 \\
70 \\
65 \\
45 \\
35 \\
20 \\
20 \\
\end{array}$ & $\begin{array}{r}1 \\
2 \\
3 \\
4 \\
16 \\
10 \\
1 \\
\end{array}$ & $\begin{array}{l}479 \cdot 0 \\
205 \cdot 0 \\
454.0 \pm 324.5 \\
111.3 \pm 58 \cdot 1 \\
203.9 \pm 55.8 \\
201.6 \pm 62.9 \\
601.0\end{array}$ & $\begin{array}{r}126-284 \\
152-916 \\
78-168 \\
72-461 \\
59-661\end{array}$ & $\begin{array}{r}1 \\
2 \\
3 \\
4 \\
15 \\
11 \\
1 \\
\end{array}$ & $\begin{array}{r}84.0 \\
42.5 \\
23.7 \pm \quad 8.3 \\
618.8 \pm 16.0 \\
61.5 \pm 15.5 \\
32.6 \pm 3.9 \\
11.0\end{array}$ & $\begin{array}{c}31-54 \\
7-42 \\
570-660 \\
6-221 \\
18-53\end{array}$ \\
\hline & \multicolumn{10}{|c|}{ Survivors } \\
\hline $\begin{array}{r}8 \\
9 \\
10 \\
11 \\
12 \\
13 \\
14 \\
15\end{array}$ & $\begin{array}{l}66 \\
22 \\
24 \\
32 \\
22 \\
72 \\
31 \\
22\end{array}$ & $\begin{array}{l}\text { M. } \\
\text { M. } \\
\text { F. } \\
\text { F. } \\
\text { M. } \\
\text { F. } \\
\text { F. } \\
\text { M. }\end{array}$ & $\begin{array}{r}14 \\
12 \\
16 \\
10 \\
7 \\
7 \\
6 \\
4\end{array}$ & $\begin{array}{r}10 \\
0 \\
5 \\
0 \\
0 \\
7 \\
0 \\
0\end{array}$ & $\begin{array}{r}9 \\
4 \\
10 \\
9 \\
10 \\
14 \\
10 \\
6\end{array}$ & $\begin{array}{r}60 \cdot 0 \pm 22 \cdot 3 \\
70.5 \pm 36.3 \\
38.5 \pm 5.7 \\
64.6 \pm 22.0 \\
74.3 \pm 25.0 \\
125.8 \pm 10.0 \\
60.9 \pm 20.2 \\
64 \cdot 2 \pm 27.4\end{array}$ & $\begin{array}{l}37-138 \\
55-101 \\
13-48 \\
54-101 \\
9-105 \\
81-329 \\
40-108 \\
46-100\end{array}$ & $\begin{array}{r}9 \\
4 \\
10 \\
9 \\
10 \\
14 \\
9 \\
6\end{array}$ & 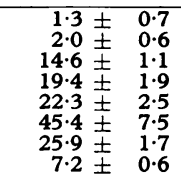 & $\begin{array}{c}0-7 \\
1-4 \\
8-18 \\
7-27 \\
15-42 \\
18-112 \\
20-35 \\
5-9\end{array}$ \\
\hline
\end{tabular}

were observed in six of the seven patients who died (fig. 3). Three of these patients (cases 3,5, and 6) survived longer than two days and in all three the glucagon concentrations became grossly increased immediately before death. Concentrations of over $250 \mathrm{ng} / 1$ were only seen in one (case 13) of the eight survivors during a septicaemic episode, which temporarily put her in group 4.

Highly significant correlations $(P<0.001)$ were obtained between

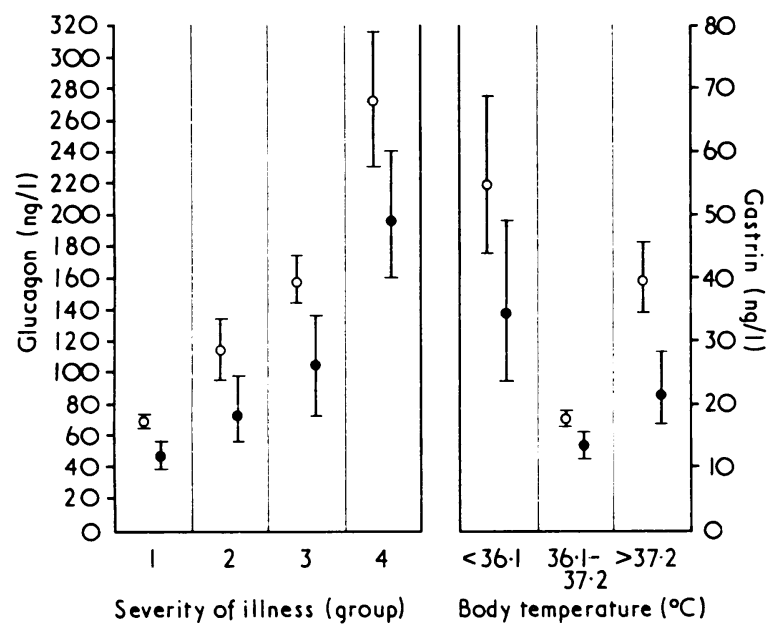

FIG. 2-Relationship of plasma glucagon ( $O$ ) and gastrin $(0)$ concentrations to severity of illness and body temperature. the plasma glucagon concentrations and serum glucose, urea, and plasma gastrin concentrations. There was also a highly significant inverse correlation $(P<0.001)$ between the plasma glucagon concentration and serum bicarbonate concentration (table III). Glucagon concentrations were related to the severity of illness and were significantly higher in patients with an abnormally high or low body temperature.

All statistical comparisons were made on logarithms (to the base 10) of the values to normalize the distribution. Where comparisons were

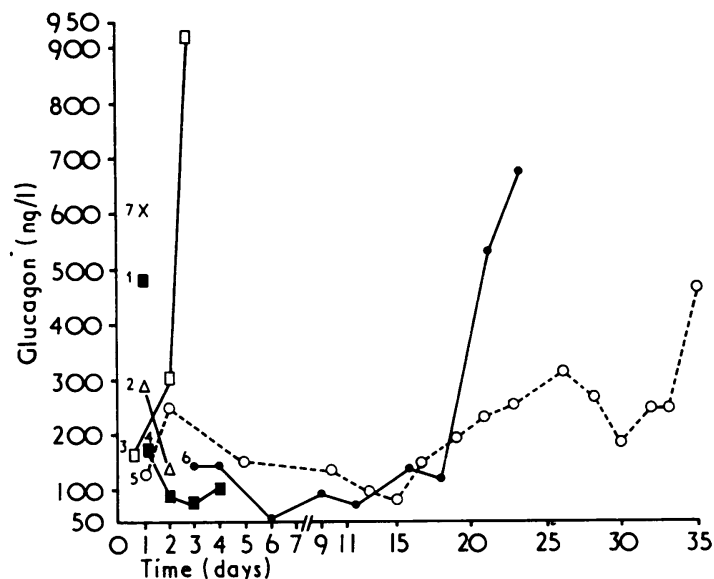

FIG. 3-Plasma glucagon concentrations in seven patients who died of burns.

TABLE II-Plasma Glucagon and Gastrin Concentrations (expressed as Logarithms) according to Body Temperature and Severity of Illness. Values from Patients with Temperatures above $37 \cdot 2^{\circ} \mathrm{C}$ or below $36 \cdot 1^{\circ} \mathrm{C}$ are compared with those from Patients within Range $36 \cdot 1-37 \cdot 2$. Values from Patients in Group 1 are compared with those from Patients in Groups 2-4

\begin{tabular}{|c|c|c|c|c|c|c|}
\hline & \multicolumn{3}{|c|}{ Glucagon } & \multicolumn{3}{|c|}{ Gastrin } \\
\hline & No. of Studies & $\underset{\text { Mean })}{\text { Mean }( \pm \text { (ng/l) }}$ & $\mathbf{P}$ & No. of Studies & $\underset{\text { Mean })}{\text { Mean }( \pm \text { Sg/l) }}$ & $\mathbf{P}$ \\
\hline $\begin{array}{l}\text { Body temperature }\left({ }^{\circ} \mathrm{C}\right): \\
<36 \cdot 1 \\
>37 \cdot 2 \\
36 \cdot 1-37 \cdot 2\end{array}$ & $\begin{array}{l}12 \\
24 \\
72\end{array}$ & $\begin{array}{l}2.34 \pm 0.098 \\
2.20 \pm 0.06 \\
1.85 \pm 0.25\end{array}$ & $\begin{array}{l}<0.001 \\
<0.001\end{array}$ & $\begin{array}{r}8 \\
23 \\
75\end{array}$ & $\begin{array}{l}1.53 \pm 0.16 \\
1.34 \pm 0.11 \\
1.12 \pm 0.075\end{array}$ & $<0.1$ \\
\hline $\begin{array}{l}\text { Severity of Illness: } \\
\text { Group } 1 \\
\text { Group } 2 \\
\text { Group } 3 \\
\text { Group } 4\end{array}$ & $\begin{array}{r}75 \\
7 \\
8 \\
19\end{array}$ & $\begin{array}{l}1.84 \pm 0.022 \\
2.05 \pm 0.075 \\
2.20 \pm 0.075 \\
2.43 \pm 0.069\end{array}$ & $\begin{array}{l}<0.01 \\
<0.001 \\
<0.001\end{array}$ & $\begin{array}{r}76 \\
7 \\
7 \\
15\end{array}$ & $\begin{array}{l}1.06 \pm 0.08 \\
1.26 \pm 0.12 \\
1.41 \pm 0.16 \\
1.69 \pm 0.08\end{array}$ & $<0.01$ \\
\hline
\end{tabular}

TABLE III-Correlation Coefficient and Significance of Correlation between Glucagon, Gastrin, and W.B.C., Glucose, Urea, and Bicarbonate

\begin{tabular}{|c|c|c|c|c|c|c|c|c|c|}
\hline & \multicolumn{5}{|c|}{ Glucagon $v$. } & \multicolumn{4}{|c|}{ Gastrin $v}$. \\
\hline & W.B.C. & Glucose & Urea & Bicarbonate & Gastrin & w.B.C. & Glucose & Urea & Bicarbonate \\
\hline $\begin{array}{r}\text { No of studies } \\
\text { P }\end{array}$ & $\underset{0.08}{76}$ & $\begin{array}{c}94 \\
0.38 \\
<0.001\end{array}$ & $\begin{array}{l}80 \\
0.70 \\
<0.001\end{array}$ & $\begin{array}{l}78 \\
<0.59 \\
<0.001\end{array}$ & $\begin{array}{l}103 \\
0.48 \\
<0.001\end{array}$ & $\begin{array}{l}73 \\
-0 \cdot 18\end{array}$ & ${ }_{-0.03}^{91}$ & $\begin{array}{c}75 \\
0.34 \\
<0.01\end{array}$ & $\begin{array}{l}74 \\
-0.25 \\
<0.05\end{array}$ \\
\hline
\end{tabular}


made in groups with differing severities of illness or temperatures intergroup comparisons of the means of the logarithmic values were made by Student's unpaired $t$ test. Case 4 was excluded from statistical analyses involving gastrin concentrations.

\section{Discussion}

Stress ulceration of the gastrointestinal tract may result from thermal burns, ${ }^{5}$ but its aetiology is obscure. Gastric acid secretion is raised in the burned patient, ${ }^{6}$ and gastrin secretion, which stimulates gastric acid production, is promoted by sympathetic adrenergic activity, which occurs in acutely stressful circumstances. Possibly stress ulcers occur as a result of excessive acid secretion provoked by hypergastrinaemia. The delay before the occurrence of these ulcers, which may present days or weeks after the initial insult, ${ }^{7}$ might be invoked by damage to the gastric mucosa, caused by ischaemia or other insults, which needs time to recover before gastric secretory function returns.

Though gastric secretion is abnormally high in burned patients the increase is less obvious in patients with the largest burns. ${ }^{6}$ In an earlier study ${ }^{8}$ only four patients out of 20 with Curling's ulcer showed evidence of acid hypersecretion, but unless serial samples are measured throughout the burn illness one cannot know whether these acid levels remain within the normal range. Another report ${ }^{9}$ recorded raised serum gastrin levels in one out of three burned patients with gastrointestinal haemorrhage, but again sampling was infrequent and could have missed the important rise observed in our patient with a Curling ulcer (Case 5). Our only patient to develop hypergastrinaemia after the immediate post-burn period was also the only patient who developed an acute gastrointestinal haemorrhage as the result of acute stress ulceration. This strongly suggests that hypersecretion of gastrin may play a part in the pathogenesis of acute stress ulcers. If this relation could be established it would be of practical value because stress ulceration carries a high mortality and prophylactic measures might be feasible.

The increase in plasma glucagon levels has already been described in burned patients ${ }^{10}$ and some of the metabolic implications discussed. We also observed raised glucagon levels in patients with major burns and, though they correlated with the percentage of surface area affected, gross increases in glucagon levels occurred when systemic complications supervened. Thus the severity of the illness seems to be a more potent stimulator of glucagon production than the burn injury itself.

Plasma glucagon concentrations are high in starvation, ${ }^{11}$ diabetes, ${ }^{12}$ severe infection, ${ }^{13}$ trauma, ${ }^{14}$ and burns. ${ }^{10}$ Under these conditions glucose is manufactured from products of protein degradation by gluconeogenesis and ketosis, and under some circumstances an accompanying acidosis results from the excessive mobilization and catabolism of fatty acids.

Glucagon is one of the most potent agents activating and inducing the enzymes of gluconeogenesis, ${ }^{15}$ and in man the infusion of this hormone results in a considerable increase in protein catabolism and urinary urea excretion. ${ }^{16}$ The close correlation between plasma concentrations of glucagon and those of urea and glucose and the inverse correlation with bicarbonate support suggestions that glucagon plays a causal part in the hypercatabolic state.

The recent discovery that growth hormone-release inhibiting hormone blocks glucagon release in man without any significant side effects ${ }^{17}$ raises the possibility that this compound may be of clinical value in limiting the metabolic derangements of hypercatabolic states induced by hyperglucagonaemia.

We thank Mr. A. J. Evans and Mr. P. J. Whitfield for their encouragement in pursuing this study in their patients. A.W.S. was supported by the Medical Research Council, and S.R.B., who is an M.R.C. clinical research fellow, also receives support from the British Diabetic Association.

\section{References}

${ }^{1}$ Evans, A. J., British fournal of Plastic Surgery, 1953, 5, 263.

2 Bloom, S. R., British Medical Bulletin, 1974, 30, 62.

3 Bloom, S. R., Gut, 1974, 15, 502.

4 Walsh, J. H., Debas, H. T., and Grossman, M. I., fournal of Clinical Investigation, 1974, 54, 477 .

${ }^{5}$ Curling, T. B., Medico-chirurgical Transactions, 1842, 25, 260.

5 Curling, T. B., Medico-chirurgical Transactions, 1842, 25, 260.
${ }^{6}$ Harrison, A. M., Gaisford, J. E., and Wechsler, R. I., fournal of Trauma, 1972, 12, 1041.

7 Shepherd, J. A., Surgery of the Acute Abdomen, 2nd ed. Livingston, London, 1968.

${ }^{8}$ O'Neill, J. A., Surgery, 1970, 67, 267.

${ }_{9}^{9}$ Newsome, T.' W., et al., Archives of Surgery, 1973, 107, 622.

10 Wilmore, D. W., et al., Lancet, 1974, 1,73.

11 Aguila-Parada, E., Eisentraut, A. M., and Unger, R. H., Diabetes, 1969, 18, 717 .

12 Unger, R. H., Madison, L. L., and Müller, W. A., Diabetes, 1972, 21, 301.

13 Rocha, D. M., et al., New England fournal of Medicine, 1973, 288, 700.

14 Meguid, M. M., et al., Surgical Forum, 1973, 24, 97.

15 Exton, J. H., et al., Recent Progress in Hormone Research, 1970, 26, 411.

16 Marliss, E. B., et al., fournal of Clinical Investigation, 1970, 49, 2256.

17 Mortimer, C. H., et al., Lancet, 1974, 1, 697.

\title{
Successful Pregnancy in Patient on Regular Dialysis
}

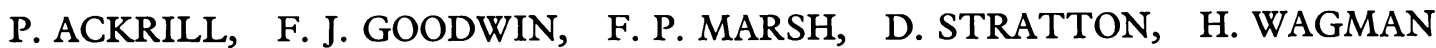

\section{Introduction}

Chronic renal failure in women is associated with irregular or absent menstruation, ${ }^{1}$ impaired fertility, ${ }^{2}$ and, if conception is achieved, a high incidence of complications and fetal wastage..$^{3-4}$ Patients on regular dialysis treatment (R.D.T.) may, however, resume normal menstruation, ovulate, ${ }^{5}$ and become pregnant, ${ }^{6}$ though most pregnancies if they do not abort spontaneously are terminated. ${ }^{6}$ Only two successful pregnancies have been reported $^{6}{ }^{7}$; we report here a third.

\section{Case Report} P. ACKRILL, M.B., M.R.C.P., Senior Registrar, Department of Nephrology.
(Present appointment: Senior Registrar, St. Bartholomew's Hospital, London E.C.1).

F. J. GOODWIN, M.B., M.R.C.P., Consultant Nephrologist

F. P. MARSH, M.B., M.R.C.P., Consultant Nephrologist

D. STRATTON, M.B., M.R.C.P., Lecturer in Paediatrics WAGMAN, F.R.C.S., M.R.C.O.G., Senior Registrar, Department of
Obstetrics and Gynaecology. (Present appointment: Consultant ObstetObstetrics and Gynaecology. (Present appc
rician, Barnet General Hospital, Herts.)
A 24-year-old nulliparous married woman developed hypertension and renal failure due to bilateral renal scarring with vesicoureteric creatinine clearance was $2.2 \mathrm{ml} / \mathrm{min}$ with a $1.0 \mathrm{~m}^{2}$ standard Kiil dialyser for 10 hours thrice weekly. Hypertension was controlled by ultrafiltration, and dialysis was later reduced to eight hours thrice reflux and recurrent bacteriuria. She began R.D.T. when her 